UDC 332.122:339.9 (066), 019

JEL Classification O 19

DOI: 10.31375 / 2226-1915-2018-1-21-30

\title{
RECREATIONAL TOURISM IN THE BORDER REGIONS: DANUBE REGION CASE OF STUDY
}

\author{
G.M. Silvanska, \\ $\mathrm{Ph}$. D. in Ecomomics \\ silva@te.net.ua \\ O.V. Akimova, \\ Ph. D. in Transport Technologies \\ olga.onmu@gmail.com \\ O.L. Drozhzhyn \\ Senior lecturer \\ drozhzhyn@efitmp.onmu.odessa.ua \\ Odesa National Maritime University, \\ Science and Educational Institute of Maritime Buisiness, Odesa, Ukraine
}

The paper is devoted to the issues of creation and development of the tourist and recreational sector of the Danube trans-boundary region. Was defited the role of the tourist sector in the national economy and cross-border regions are determined. Reserched the structure of the target program for the development of cross-border tourism, the main prerequisites for the creation of cross-border tourist clusters, the main problems of development were formulated and fixed.

Keywords: Low Danube region, Odessa region, Tulcea region, UkrainianRomanian cross-border region, cross-border region recreation, European regional cooperation.

\section{РЕКРЕАЦІЙНИЙ ТУРИЗМ ТРАНСКОРДОННИХ РЕГІОНІВ: ТЕРРИТОРИЯ ПРИДУНАВЬЯ}

\section{Г.М. Сільванська,}

к.е.н., доиент, дочент кафедри «Експлуатачія флоту і технології морських перевезень» silva@te.net.ua

О.В. Акімова,

к.т.н., дочент, доцент кафедри «Експлуатація флоту і технології морських перевезень» olga.onтu@gmail.com

о.Л. Дрожжин

старший викладач кафедри «Експлуатація флоту і технології морських перевезень» drozhzhyn@efitmp.onmu.odessa.ua

Одеський начіональний морський університет, Науково-навчальний інститут морського бізнесу, Одеса, Украӥна

В даний час Європейський Союз переживає безпреиедентний за своӥм значенням процес ретериторіалізаиії в контексті інтеграції в Свропейський Союз. Центральною у изому процесі є реалізація різних схем транскордонного співробітництва, широко відомих як «Концепиія Сврорегіонів», до яких належить й регіон «Нижній Дунай», щуо досліджується.

(C) Silvanska G.M., Akimova O.V., Drozhzhyn O.L., 2018 
DEVELOPMENT OF MANAGEMENT

AND ENTREPRENEURSHIP METHODS

ON TRANSPORT, № 1(62), 2018
РОЗВИТОК МЕТОДІВ УПРАВЛІННЯ

ТА ГОСПОДАРЮВАННЯ

НА ТРАНСПОРТІ, № 1(62), 2018

Статтю присвячено питанням формування та розвитку туристичнорекреаційної сфери Придунайського транскордонного регіону (розглядається Ізмаїльський район Одеської області, Украӥна й жудецьь Тулча, Румунія). Визначено сутність та роль туристичної сфери в начіональній економічі та транскордонних регіонах. Досліджено змістовну структуру иільової програми розвитку транскордонного туризму, основні передумови для створення транскордонних туристичних кластерів, зазначені основні проблеми розвитку туристичної галузі. Сврорегіональна концепџія, а також кооперачія в формі міжнародної уніфікаџії туристичного законодавства базується на співпраці урядів краӥн і громадянського суспільства на базі взаємних економічних та політичних інтересів окремих територій. Відповідно до иієї концепиії, майбутня Свропа трактується не як територія окремих суверенних європейських держав, але як Свропа регіонів, щяо мають спільний історико-етнографічний фон, значні економічні інтереси і бізнес-зв'язки на міжнародному рівні. В роботі визначено пріоритетні напрямки взаємодіі Украӥни і Румунії в туристично-рекреаційноїму контексті, які б стимулювали розвиток зазначеної Концепиії в сфері туризму і рекреаиії. Це дослідження має на меті визначити, які саме сфери транскордонного туристичного співробітництва можуть сприяти розвитку та проивітанню внутрішньому розвитку Свропейського Союзу та його регіональних партнерів в Сврорегіоні «Нижній Дунай», зокрема на території украӥнського Придунав'я.

Ключові слова: регіон нижнього Дунаю, Одеська область, жудець Тульча, украӥнсько-румунський прикордонний регіон, відпочинок на прикордонних територіях, європейське регіональне співробітниитво.

\section{РЕКРЕАЦИОННЫЙ ТУРИЗМ ТРАНСГРАНИЧНЫХ РЕГИОНОВ: ТЕРРИТОРИЯ ПРИДУНАВЬЯ}

Г.Н. Сильванская,

к.э.н., доцент, доцент кафедры «Эксплуатация флота и технологии морских перевозок»

О.В. Акимова,

к.т.н., дочент, доцент кафедры «Эксплуатация флота и технологии морских перевозок» А.Л. Дрожжин

старший преподаватель кафедры «Эксплуатация флота и технологии морских перевозок»

Одесский национальный морской университет,

Научно-учебный институт морского бизнеса, Одесса, Украина

Статья посвящена вопросам формирования и развития туристско-рекреаичинной сферы Придунайского трансграничного региона. Определена сущность и роль туристической сферы в национальной экономике и трансграничных регионах. Исследована содержательная структура иелевой программы развития трансграничного туризма, основные предпосылки для создания трансграничных туристических кластеров, указаны основные проблемы развития.

Ключевые слова: регион нижнего Дуная, Одесская область, жудеи Тулча, украинский-румынский пограничный регион, отдых на приграничных территориях, европейское региональное сотрудничество. 
Problem statement. The development of regional recreational tourism in the context of cross-border cooperation is an extremely important task not only of a national scale, but also of interest to our neighboring countries. The territory of the Ukrainian Danube is a unique complex of diverse natural and cultural/historical objects, the combination of which causes the formation of a huge number of many types of natural and recreational resources. This region occupies one of the leading places in tourism potential and it's natural, historical and cultural resources, which can stimulate considerable interest among domestic and foreign tourists.

In the sector of cross-border tourism cooperation, today there are significant issues related to problems of national low regulation of interregional relations, as well as local approaches to their implementation. For example, the regulatory framework of Romania, as our closest Danube neighbor, and Ukraine, have significant differences in the low regulation of interregional and cross-border cooperation, both at the level of laws and by-laws acts.

The focus of this paper - is the conditions for the progressive development of the recreational and tourist industry in the region and the form of effective use of the tourist and recreational potential of the Danube for the development of tourism products based on the strategic management and interaction of large, medium and small businesses and the attraction of domesticukrainian and foreign investments.

Recent research and publications analysis. All existing problems of recreation can be considered from the point of view of the different science sectors: geography, ecology, enterprise economics, regional economy, transport technology and systems, etc. Sometimes, the issues of the problems of recreation of transboundary regions are considered as the problems of international law and political science.

The analysis of some tourist products in regional markets, in particular the theme of the Danube cruises, is devoted to papers (Dragin, Dragin \& Plavsa, 2007), (Ploner, 2009). The regional cross-border cooperation between Croatia and Serbia in aspect of the investment effectiveness in the tourism industry described at (Vujko, A., \& Gajic, 2014. Ecotourism problems of the Danube Delta study in the articles of European authors (Hall, 1993), (Montanari, Williams \& Allan M, 1995), (Turnock, 2002)., (Assche, \& Teampau, 2012), (Văidianu, Paraschiv \& Saghin, 2015), (Pavel-Nedea \& Dona 2017), etc. The prospects of rural tourism in the context of the ecotourism of the SlovakHungarian border were investigated in (Jakubcova, Grezo \& Petrovic, 2015).

Ukrainian scientists also studied the issues found of cross-border tourist cooperation of Ukraine with EU contries (Shevchenko-Marsel \& Rusyna, 2007), (Nelin, 2014), (Bil, 2008), (Bielievtseva, 2006).

The goal of this article. The study aims to analyze the objective basis for the development of trans-boundary tourism in Ukraine-Romania cooperation (in the context of the Odessa region, Ukraine/Tulcea, Romania) as a phenomenon of social life and object of scientific knowledge.

The basic results and their justification. The recreational tourism is a potentially investment-attractive type of economic activity within the Ukrainian-Romanian transborder region ( $\mathrm{Za}-$ 
karpattia, Ivano-Frankivsk, Chernivtsi and Odesa regions). However, today, the level of implementation of its potential remains low and, moreover, there are every reason to assert the disnalance of it's development in Ukraine and Romania, which are due in the first place to differences in institutional provision due to:

- significant differences in the organizational, economic and legal regulation of tourism in Ukraine and Romania;

- insufficient cooperation between individual Ukrainian and Romanian tourist organizations;

- differences in priorities and programming of cross-border tourism development at the state and regional level.

The current development of cross-border tourism, which is based on the main elements - touristic steam volomes, integration, social/economic type significantly influenced the dynamics of the tourism market and led to consider tourism as a social and economic phenomenon. The development of tourism industry in Ukraine, which would successfully integrate into international tourist relations, is one of the leading areas for the structural adjustment of the country's economy. Favorable conditions for the formation of a national market for competitive tourism services should be created by the state on the basis of new economic mechanisms in an open economy (Hontarzhevs'ka, 2008).

In December 2015, the Romania-Ukraine Program was prepared and approved the European Neighborhood Instrument (ENI). According to this document, in the period 2014-2020, the European Union will finance the Joint
Operational Program (JOP) Romania Ukraine 2014-2020. The general objective of the Romania-Ukraine Joint Operational Programme is to enhance the economic development and to improve the quality of life of the people in the programme area through joint investments in education, economic development, culture, infrastructure and health while ensuring the safety and security of the citizens in the two countries

According to JOP 2014-2020, the varied relief, the geographical positioning, the varied flora and fauna, and the cultural heritage of the area are key components that can form the base for developing the tourism infrastructure and services. The area benefits from over 1070 natural protected areas of national and international importance and numerous historic sites. These are important points of attraction for national and international tourists, as proven by the number of overnight stays.

In the Romania-Ukraine core eligible area the most important and utilized navigable route is the Danube, and its three arms unravelling in Tulcea County: Chilia, Sulina and Sfântul Gheorghe.

However, the traffic on the Danube is fairly limited due to the underdevelopment of the navigable canals, in spite of the direct link to the Danube Delta, the possible connectivity with Galati and Tulcea ports, and the link with the Black Sea, which could open more opportunities in terms of international freight and passenger traffic.

The most important ports in the core eligible touristic area are Tulcea river/sea port, Sulina, Chilia and Sfântul Gheorghe in Romania, and Izmail, Reni, Ust-Dunaisk in Ukraine. To the Roma- 
nian side two more large ports contribute to the economic environment of the area: Brăila and Galati, located in the neighbouring counties. Galați and Tulcea are the two main ports on the Danube as these ensure the linkage between the river and the Black Sea and the inter-modal change between means of transport (naval-road-rail).

One of the major issues regarding border crossing between Romania and Ukraine is represented by the limitations in this respect of the Southern area of the core eligible area, i.e. Tulcea County - Odessa Oblast. Due to the geographical specificities of the area and the relief characteristic of the Danube Delta there are no borders crossing points between the two states. As a result, the Romania-Ukraine border cros-sing traffic has to be rerouted via
Republic of Moldova, through the Galați-Giurgiulești border crossing point, while entrance into Ukraine can be made through several points, the closest in terms of distance being Giurgiulești-Reni and Vulcănești-Vinogradovka border crossing points. This detour increases traveling times with significant impacts on economic activities, as well as supplementary complications in terms of international transit law. sist of:

Program territories (figure) con-

- Romania: Baia-Mare, SatuMare, Suceava, Botoșani and Tulcea;

- Ukraine: Ivano-Frankivsk, Transcarpathian, Chernivtsi, Odessa.

$60 \mathrm{mln}$. euro.

EU funding for this program is

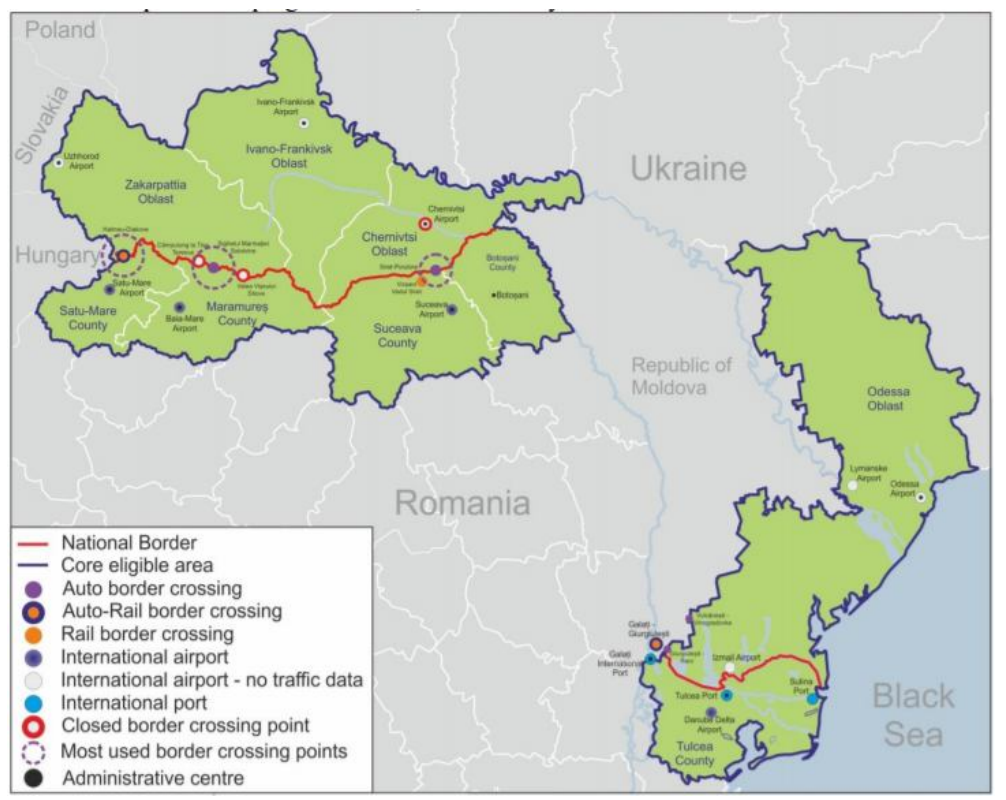

Core area of the paper (Source: www.mdrap.ro) 
Looking at the geography and characteristics of human settlements it should be mentioned that the positioning of large rural areas between the main urban centres, having limited access to services and amenities characteristic to urban areas. This factor negatively affects the accessibility to tourism, healthcare or social assistance services, mostly for the rural area (tabl. 1).

Table 1

\section{Strengths and weaknesses of touristic cooperation in trans-border Ukraine-Romania border}

\begin{tabular}{|l|l|}
\hline \multicolumn{1}{|c|}{ Strengths } & \multicolumn{1}{c|}{ Weaknesses } \\
\hline $\begin{array}{l}\text { New and undiscovered area with significant } \\
\text { recreational and balneological resources; }\end{array}$ & $\begin{array}{l}\text { Extremely different topography across the Low } \\
\text { Danube (Judeţul Tulcea and Odessa region); }\end{array}$ \\
\hline $\begin{array}{l}\text { Complex hydrographic network: many lakes } \\
\text { and estuaries, important rivers and Danube } \\
\text { together with its Delta; }\end{array}$ & $\begin{array}{l}\text { Large unpopulated areas and rural areas, } \\
\text { especially in the areas of Judeţul Tulcea and } \\
\text { Odessa region; }\end{array}$ \\
\hline $\begin{array}{l}\text { Presence of the powerful urban pole of } \\
\text { Odessa-city; }\end{array}$ & $\begin{array}{l}\text { Large urbanization gaps between the main } \\
\text { urban centres; }\end{array}$ \\
\hline $\begin{array}{l}\text { Possibilities of diversification of the tourist } \\
\text { services market: green, ecological, } \\
\text { gastronomic, ethnographic, medical, on } \\
\text { organization and holding of business events, } \\
\text { event tourism; }\end{array}$ & $\begin{array}{l}\text { Mountainous areas and the natural deltas } \\
\text { hinder urban and infrastructure development; }\end{array}$ \\
\hline $\begin{array}{l}\text { Various relief forms as: mountains, hills, } \\
\text { plains presenting advantages for agricultural } \\
\text { and tourism development; }\end{array}$ & $\begin{array}{l}\text { Lack of a holistic systemic state policy of } \\
\text { development and tourist support of the } \\
\text { industry, low level of information support of } \\
\text { tourism activity; }\end{array}$ \\
\hline $\begin{array}{l}\text { Important urban centres of both sides of the } \\
\text { border concentrating a large urban population; }\end{array}$ & $\begin{array}{l}\text { Urban population ratio under the national ave- } \\
\text { rage in Judeţul Tulcea and Odessa region; }\end{array}$ \\
\hline $\begin{array}{l}\text { The Ukrainian regions have a positive natural } \\
\text { increase ratio of population; }\end{array}$ & $\begin{array}{l}\text { The Romanian counties are confronted with a } \\
\text { negative natural increase ratio of the } \\
\text { population; }\end{array}$ \\
\hline $\begin{array}{l}\text { Developed agriculture, forestry, fishing and } \\
\text { food industry activities, strong potential for } \\
\text { tourism in general and agro-tourism in special; }\end{array}$ & $\begin{array}{l}\text { The main economic activities have low value } \\
\text { added (agriculture, fishing, trade and tourism } \\
\text { related services); }\end{array}$ \\
\hline Numerous cultural and natural elements. & Pollution (domestic, industrial). \\
\hline
\end{tabular}

Recreation rerion-forming centers of the Odessa region, which adjoin the state border with Romania, are concentrated in three towns: Izmail, Kilia and Reni districts. In the monograph (Honcharenko, 2014) mentioned area classified to the $5 \mathrm{~A}$ group, is designated «Reni-Kilia region, Low Danube» and is characterized as a favorable, aesthetic-recreational-excursion, climatic-balneo-logical, high recreational and man-made load, and secondary development of recreational infrastructure. These include such villages: v. Ok- 
samytne, v. Vladychen', v. Krynychne, v. Kosa, v. Kot-lovyna, v. Lymans'ke, v. Nahirne, v. Plavni, v. Novosil's'ke, v. Nova Nekrasivka, v. Ozerne, v. Suvorovs'ke, v. Vasylivka, v. Prymors'ke. There are 77 restoration points (hotels, sanatorium and spa establishments, children's recreation facilities) and 4 recreational areas (hunting and fishing farms, state forest hunting grounds, etc.) in this zone.

The peculiarity of the touristicexcursion potential of the Danube Odesa region is determined by numerous monuments of various times with wellknown historical and cultural reserves, monuments and museums. These are the world-famous Ukrainian Venice - the Vilkovo town, fortresses, monuments of religious architecture in the cities of Odessa, Izmail, Reni, Kilia.

The Reni-Kilia border region is a complex landscape and recreational region (LRR) of ecological, historical and ethnographic and religious areas of recreational activity, with the elements of health and watersport recreation activity.

Conclusions. In general, the border-region of the Ukrainian Danube is considered as a landscape-recreational center, the specialization of which is focused on the medical-health and historical-cognitive direction. The recreational area is focused on the implementation of full recreational cycles and on «weekend tours» for the local population in the form of hunting/fishing recreation. Promising areas for the development of recreation are health and wellness (Primors'ke village), ecological (Green tourism) tourism within protected areas (The Danube Delta Biosphere Reserve «Ostriv Zmiyinyy», «Izmayil's'ki Ostrovy» - Small Daler, Great Daler and Tataru, wetlands lands of international importance), rural hunting tourism (la-kes Yalpug-Kugurlui, Cahul, Kytai). Perspective directions are also: historical, ethnographic (the city of Izmail, a number of settlements of the Ismayil region), religious tourism (Lipovansky churches near Vilkovo).

\section{REFERENCES}

1. Assche, K. V., Bell, S., \& Teampau, P. (2012). Traumatic Natures of the Swamp: Concepts of Nature in the Romanian Danube Delta. Environmental Values, 21(2), 163-183. doi:10.3197/096327112x13303670567297 [in English].

2. Basiuk O. V. \& Navrozova, Yu. O. (2013). Rozvytok turyzmu v umovakh novoi ekonomiky [Development of tourism in a new economy]. Rozvytok metodiv upravlinnia ta hospodariuvannia na transporti - Development of administration and economic management methods on transport, № 2 (43), 86-97 [in Ukrainian].

3. Bielievtseva, V. V. (2006) Prykordonna kooperatsiia: yevrorehiony yak mosty komunikatsii [Border Cooperation: Euroregions as Bridges of Communication]. Visnyk Kharkivskoho natsionalnoho universytetu vnutrishnikh sprav - Bulletin of Kharkiv National University of Internal Affairs, № 33: p. 270-276 [in Ukrainian]. 
4. Bil, M. (2008) Transkordonne spivrobitnytstvo rehioniv Ukrainy $v$ haluzi turyzmu: suchasnyi stan ta osnovni napriamky rozvytku [Transboundary cooperation regions of Ukraine. in the field of tourism: the modern state. and main developments]. Demokratychne vriaduvannia: naukovyi visnyk Democratic governance: electronic academic publication, № 2 [in Ukrainian].

5. Dragin, A., Dragin, V., Plavsa, J., Ivkov, A., \& Djurdjev, B. (2007). Cruise ship tourism on the Danube in Vojvodina Province as a segment of global tourism. Geographica Pannonica, (11), 59-64. doi:10.5937/geopan0711059 [in English].

6. Dragin, A., Jovičći, D., \& Bošković, D. (2010). Economic Impact of Cruise Tourism along the Paneuropean Corridor VII. Economic researchEkonomska istraživanja, 23(4), 127-141. [in English].

7. Fylypenko, A., Makoukh, V., \& Savchenko, A. (2014). The Danube strategy and it's impact on the process of Ukraine-EU Rapprochement. EUROPEAN UNION IN TIMES OF CRISIS, 120 [in English].

8. Hall, D. R. (1993). Ecotourism in the Danube Delta. The Tourist Review, 48(3), 11-13. doi:10.1108/eb058125 [in English].

9. Homepage RBDD - REZERVATIA BIOSFEREI DELTA DUNARII. (n.d.). http://www.ddbra.ro. Retrieved February 25, 2018, from http://www.ddbra. ro/ [in Romanian].

10. Honcharenko Ya. Ye. (2014) Modeliuvannia rozvytku turystsko-rekreatsiinoho kompleksu na prykladi Odeskoho rehionu [Modeling the development of a tourist-recreational complex on the example of the Odessa region]: Kherson: Hrin D. S [in Ukrainian].

11. Hontarzhevs'ka L. I. (2008) Rynok turystychnykh posluh v Ukrayini [Market of tourist services in Ukraine.]. Donetsk: Skhidnyy vydavnychyy dim. p.180. [in Ukrainian].

12. Jakubcova, A., Grezo, H., Petrovic, F. (2015). A proposal of recreational landscape connection with the function of nature protection within crossborder networks (in Slovak-Hungarian buffer zone). Aktuálni problémy cestovniho ruchu. Tourism: Development - Transformation - Future prospects. College of Polytechnics Jihlava [in English].

13. Joint Operational Programme Romania - Ukraine 2014-2020. (n.d.). http://www.ro-ua-md.net. Retrieved February 25, 2018, from http://www. ro-ua-md.net/wp-content/uploads/2016/01/0-Romania-Ukraine-JOP-approved2.pdf. [in English].

14. Mazilu, M., Bala, D., Dumitrescu, L., \& Baltalunga, A. A. (2014). Revitalization of the Danube port-cities through tourism. 14th SGEM GeoConference on Ecology, Economics, Education And Legislation, 2 (SGEM 2014 Confe-rence Proceedings), ISBN 978-619-7105-18-6/ISSN 1314-2704, June 19-25, 2014, Vol. 2, 611-618. [in English].

15. Ministerul Dezvoltarii Regionale si Administratiei Publice - MDRAP. (n.d.). Retrieved February 25, 2018, from http://www.mdrap.ro/dezvoltareregionala/-4970/-7572/-9495 [in Romanian]. 
16. Montanari, A., Williams, Allan M. (ed.). (1995) European Tourism: Regions, spaces and restructuring. John Wiley \& Son Limited [in English].

17. Navrozova Yu. O. (2016). Foreign experience in the creation of tourist clusters as a tool for improving the competitiveness of the Odessa region. Proceedings from $V$ Vseukr. nauk.-praktychna konferentsiia studentiv ta molodykh vchenykh "Problemy i perspektyvy rozvytku transportu» - The 5th Ukrainian Scientific and Practical Conference of the Students ang Young Scientists "The problems and perspectives of transport development». (pp. 233-235). Odesa: ONMU [in English].

18. Nelin, O. (2014) Aktualni pytannia pravovoho rehuliuvannia turyzmu $v$ Ukraini $v$ konteksti yevropeiskoi intehratsii i harmonizatsii natsionalnoho zakonodavstva [Topical issues of legal regulation of tourism in Ukraine in the context of European integration and harmonization of national legislation]. Yurydychna Ukraina - Legal Ukraine, № 12, 4-9 [in Ukrainian].

19. Pavel-Nedea, A., \& Dona, I. (2017). Assessement of the touristic demand in the Danube Delta by profile and motivation of tourists. Scientific Papers Series-Management, Economic Engineering in Agriculture and Rural Development, 17(3), 283-286 [in English].

20. Ploner, J. (2009). Narrating regional identity in tourism - sketches from the Austrian Danube valley. Language and Intercultural Communication, 9(1), 2-14. doi:10.1080/14708470802684465 [in English].

21. Prohrama rozvytku turyzmu ta kurortiv v odeskii oblasti na 2017 - 2020 rr. Dodatok do rishennia oblasnoi rady vid 23 hrudnia 2016 roku No. 285-VII. [Program of development of tourism and resorts in the Odesa region for 2017-2020. Annex to the decision of the regional council dated December 23, 2016, No. 285-VII]. https://oda.odessa.gov.ua (n.d.). Retrieved February 25, 2018, from https://oda.odessa.gov.ua/53/52281/78913/78936/ .pdf $[$ in Ukrainian].

22. Shevchenko-Marsel V.I \& Rusyna N.S. (2007). Vdoskonalennia investytsiinoho zabezpechennia rozvytku prykordonnoho rehionu [Improvement of investment support for the development of the frontier region]. Visnyk natsionalnoho universytetu "Lvivska politekhnika» - Visnyk of Lviv polytechnic national university, № 19, 168-174 [in Ukrainian].

23. Turnock, D. (2002). Prospects for sustainable rural cultural tourism in Maramure y, Romania. Tourism Geographies, 4 (1), 62-94. doi:10.1080/ 146166800110102625 [in English].

24. Văidianu, N., et al. (2015). Social-ecological consequences of planning and development policies in the Danube Delta Biosphere Reserve, Romania. Carpathian Journal of Earth and Environmental Sciences, 10.3, : 113-124. DOI: 0.1007/978-3-642-39739-4_19 [in English]. 
25. Vujko, A., \& Gajic, T. (2014). Opportunities for tourism development and cooperation in the region by improving the quality of tourism services - the 'Danube Cycle Route' case study. Economic Research-Ekonomska Istraživanja, 27(1), 847-860. doi:10.1080/1331677x.2014.975517 [in English].

26. Zhikhareva V. V. \& Vlasenko O. S. (2017) Perspektivy razvitiya turisticheskoy otrasli $v$ Ukraine [Prospects for the development of the tourism industry in Ukraine]. Stolichnyy ekspress - Capital express, № 2, 75-81 [in Russian].

Стаття надійшла до редакиії 19.02.2018

Reference a JournalArticle / Посилання на статтю: Recreational tourism in the border regions. Danube region case of study / G.M. Silvanska, O.V. Akimova, O.L. Drozhzhyn // Development of administration and economic management methods on transport: Collection. - 2018. - № 1(62). - P. 21-30. 